\title{
An exploratory study of the determinants of the quality of strategic decision implementation in Turkish industrial firms ${ }^{1}$
}

\author{
Said Elbanna* \\ Associate Professor of Strategic Management \\ Qatar University \\ P.O. Box: 2713 Doha, Qatar \\ Email: Said.Elbanna@qu.edu.qa
}

\section{Ioannis C. Thanos}

Lecturer in Strategy (Management), Adam Smith Business School, University of Glasgow Glasgow, G12 8QQ, UK

Tel: (+44) 141-330 2709

Email: ioannis.thanos@glasgow.ac.uk

\author{
Mustafa Colak \\ Assistant Professor of Strategic Management, United Arab Emirates University \\ P.O. Box: $15551 \mathrm{Al}$ Ain, UAE \\ E-mail: MColak@uaeu.ac.ae
}

* Corresponding author

\footnotetext{
${ }^{1}$ This research was funded by a research grant from UAE University (01-03-4-11/09) and was also partially supported by another research grant from the National Research Foundation in the UAE (RSA-1108-00788). The contributions of the three authors are equal. The authors thank Mumin Dayan and Mohamed Elbashir for their contributions.
} 


\title{
An exploratory study of the determinants of the quality of strategic decision implementation in Turkish industrial firms
}

\begin{abstract}
This paper investigates the determinants of quality of decision implementation. By drawing on a sample of 116 firms located in Turkey, we test whether the features of important team processes (i.e., trust and participation), of the organization (i.e. past performance) and of implementation (i.e., its speed and uncertainty) exert an influence on the quality with which decisions are implemented. Exploratory and confirmatory factor analyses were used to test the validity of the measures, while path analysis was used in hypotheses testing. The results suggest that quality of decision implementation is positively related to trust, participation and past performance, and negatively to implementation speed and uncertainty. The implications of these findings for theory, practice and general management are discussed.
\end{abstract}

Key words: quality of decision implementation; strategic decision; participation; trust; uncertainty of decision implementation 


\section{INTRODUCTION}

With small variations, the previous reviews of the literature have classified strategic management studies into two distinct categories, namely, "content" and "process" research (Elbanna, 2006). This study belongs to the second category and attempts to fill a substantial gap in the literature by studying the determinants of the quality of decision implementation.

Pettigrew (2003) argues that a decision process is composed of steps taken in both the formulation and the implementation stage of a decision, and that an understanding of the process followed for a decision should include both these two elements. Still, a recent review of the literature in strategic decision making concluded that most process studies focus exclusively on the formulation stage of a decision (Papadakis, Thanos, and Barwise, 2010).This is surprising, given that half of all decisions fail, not in the formulation stage, but due to problems confronted in their implementation (Nutt, 1999) and that well-crafted strategies lead to good organizational outcomes only if implemented properly (Noble, 1999). In this paper, we seek to cast light on this critical issue, the implementation of strategic decisions, which increases the importance of our study.

Another driving force of our research is that most empirical studies of strategy processes have a context in the U.S. (see Elbanna, 2006). Therefore, research outside the Western context is welcomed for allowing researchers to examine whether the national context shapes the ways in which decisions are made and implemented in organizations (Papadakis et al., 2010). With the above in mind, we conducted our study in a lessresearched country (i.e., Turkey) with the aim of examining determinants of the quality of decision implementation. Thanks to its location and historical ties, Turkey has geographical, cultural, and linguistic proximities to the Middle East, Central Asia, and 
Europe. The governments of Turkey have been undertaking major reforms since the early 1980s to develop a market economy. These efforts have meant new challenges and increased competition from foreign companies, which made Turkish firms more conscious about strategic planning practices (Tatoglu and Demirbag, 2008). Because Turkey is a less researched country where strategic planning practices are just gaining popularity, it presents an ideal setting in which to conduct our study on strategy implementation and to ascertain whether previous findings from developed countries may apply in developing countries (Demirbag et al., 2010; Elbanna, 2008).

From the standpoint of practice, our study can contribute to bring the attention of practitioners to some important determinants of the quality of decision implementation. That is, the capability of the firm which takes the steps and follows the procedures in order to properly execute strategic decisions.

\section{THEORY AND HYPOTHESES}

Drawing on previous models of strategic decision making (e.g., Elbanna and Child, 2007a; Papadakis, Lioukas, and Chambers, 1998) and implementation (e.g., Dooley, Fryxell, and Judge, 2000; Noble, 1999), we developed a model where the quality of implementation (i.e., how well a strategic decision has been implemented) is shaped by important team processes (i.e., trust and participation), organizational characteristics (i.e., past performance) and the characteristics of the implementation process (i.e., its uncertainty and speed) (see Figure 1).

Insert Figure 1 here 


\section{Team processes}

In this study, we focus on trust and participation which have received great theoretical and empirical attention in the literature, due to their fundamental importance in influencing decision and organizational outcomes (Andersen, 2004; Olson, Parayitam, and Bao, 2007; Wooldridge and Floyd, 1990).

\section{Trust and the quality of decision implementation}

Trust has been conceptualized in various ways, with some studies distinguishing between cognition and affective based trust (Parayitam and Dooley, 2009). We define trust as the extent to which participants feel that they could rely on each other and could openly share information when making the decision (Ford and Gioia, 2000). It is often postulated that trust leads to good decision and organizational outcomes (Gilbert et al., 2011).

We expect that trust will lead to good implementation outcomes because it can be an effective mechanism for resolving conflict (Delerue, 2005; Zaheer, McEvily, and Perrone, 1998). With trust, people are more willing to share their views, are more open to exchanging ideas and talking about their preferences and interests regarding the decision; information generally flows well when people are trusted (Peters and Karren, 2009). This leads to very low levels of political activity and destructive conflict in organizations. Based on such arguments, various scholars (e.g., Jiang, Gao, and Li, 2008; Krishnan, Martin, and Noorderhaven, 2006) have argued that trust among the top management team members is positively associated with alliance stability and alliance performance. Hence:

Hypothesis 1: Trust during the strategic decision making will be positively related to the quality of decision implementation.

Participation and the quality of decision implementation 
Andersen (2004) argues for the importance of participatory decision-making in strategy outcomes. He claims that participation in strategic decisions results in more perspectives from different participants, which may be expected to lead to better decision outcomes. Participation, in this study, refers to the degree of involvement from the people concerned, who represent different decision making levels (e.g., CEOs, groups of senior managers, middle and lower managers), in the making of strategic decisions (Elbanna, 2008; Papadakis et al., 1998).

We argue that participation enhances the quality of decision implementation through building consensus and commitment, which are prerequisites for effective implementation (Dooley et al., 2000; Kellermanns et al., 2011). As Papadakis (1998: p.117) puts it, the "involvement of more people in strategic decision making, increases the level of consensus on strategy among managers, produces a common understanding of the joint task, creates a climate of shared effort and facilitates smooth implementation". For example, including managers from the middle level of the organization in the decision making ensures that the voices and views of the lower levels of the organization will be taken into consideration before any resource allocation (Wooldridge and Floyd, 1990). This could result in better decisions by creating new ideas and developing new ways of implementing decisions (Andersen and Nielsen, 2009).

From the standpoint of commitment, having invested time, effort and resources in the decision making process makes participants feel more committed to implementation (Miller, 2008). This commitment is necessary for motivating tactics and behaviors which are essential for coordinating diverse activities in the implementation stage of the decision (Dooley et al., 2000; Wooldridge and Floyd, 1990). Arguments for the relationship 
between commitment to implementation and success can also be traced in the total quality management literature, where lack of team commitment has been found to negatively influence the successful implementation of total quality management programs (e.g., Riehl, 1988). The involvement of front line employees in the formulation stage of a decision can inform decision makers about the course of the subsequent implementation, day-to-day problems in particular, in the light of similar decisions implemented in the past.

A number of empirical studies undertaken in Turkey also point to the positive outcomes of participation. For example, Zehir and Ozsahin (2006), in a study of 73 largescale manufacturing firms in Turkey, found a positive relationship between managerial participation in decision making and organizational performance. Similarly, Eker (2008), in a sample drawn from the largest 500 firms in Turkey, reported that participation in budget planning is positively related to higher levels of managerial performance.

In conclusion, as noted by Simon (1993: p.138) “participation of many organization members in the strategic planning process is the surest way of securing the dissemination of ideas that is the basis for implementation." Hence:

Hypothesis 2: The level of participation in the strategic decision making process will be positively related to the quality of decision implementation.

\section{Organizational Characteristics}

Past performance and the quality of decision implementation

Past performance has been studied in several papers focusing on strategic decision making (e.g., Amason and Mooney, 2008; Papadakis, 1998). Though performance is a significant driver for managers' behavior (Ashmos, Duchon, and McDaniel, 1998), as far as 
we are aware, no previous studies have explicitly addressed the role of past performance in the quality of decision implementation.

High performance enables decision-makers to look for and analyze more the relevant information (e.g., Elbanna and Child, 2007b) to effectively make and implement important decisions. For example, on the basis of data analyzed from 34 decisions in five British firms, Rodrigues and Hickson (1995) found that the existence of sufficient tangible and intangible resources for a decision-making process is more likely to be associated with a successful decision.

Given the fact that the effectiveness of a strategic decision relates to its making and implementation, we claim that the better performing the firm, the better the quality of decision implementation. For instance, highly performing firms are more likely to provide

the required resources, skilled people and effective work systems to properly implement important decisions and hence raise the quality of their implementation. Highly performing firms are also likely to consider relatively full information and knowledge about environmental constraints and hence to reconcile the implementation process with environmental reality. Hence:

Hypothesis 3: Past performance will be positively related to the quality of decision implementation.

\section{Characteristics of decision implementation}

Speed and uncertainty are important determinants of strategic decision processes. (Rajagopalan et al., 1993). Still, we are not aware of any study in the implementation literature examining the speed and uncertainty characteristics of the process. Speed and the quality of decision implementation 
The speed of decision implementation is defined as the time period needed in months from the start of the implementation process to its completion (Dooley et al., 2000). Quickly implemented strategies should be desirable for the firm for at least three reasons. The first reason is implied by the slogan "time is money"; that is, the firm may be able to generate a "first mover" advantage (Makadok, 1998) by quickly implementing a decision. As pointed out by Porter and Millar (1985), the source of a temporary competitive advantage is not the right decision in itself, but rather the making and implementing of the right decision quickly. The reason is that quickly formulated and implemented decisions enable organizations to introduce new products or gain efficiency producing new technologies and processes (Baum and Wallly, 2003). In their study of 73 Turkish firms, Zehir and Ozsahin (2008) highlighted the benefits of quick decision making and implementation for organizations, such as improving innovation performance. The second reason is that speedy implementation may mitigate the cost of slow decision making processes (Atuahene-Gima and Murray, 2004); that is, a firm which is late in making a certain decision may (partially) overcome such a disadvantage by quickly implementing this decision.

The third reason is that speed affects firm performance. For example, Bourgeois and Eisenhardt (1988) argue that, in a dynamic environment, speed in decision making leads to good organizational outcomes. Judge and Miller (1991) echo this finding across various environmental contexts.

Taken together, these findings, on the relationship between speed and performance support the central argument in Eisenhardt's study (1989) that top management teams (TMTs) in high velocity environments "are able to inject a considerable amount of 
rationality into their decision processes without an adverse impact on decision speed" (Clark and Collins, 2002: p.2). This is because such environments do not necessarily reduce the decision makers' capacity to process information.

Because the implementation process depends on the implementers' information processing capabilities and because individuals can effectively engage in information processing activities in most settings, we postulate that implementers (managers) should be able to inject speed into the implementation process without an adverse impact on implementation quality. Hence:

Hypothesis 4: The speed of decision implementation will be positively related to the quality of decision implementation.

Uncertainty and the quality of decision implementation

The uncertainty of decision implementation taps into the uncertainty about the way to implement a specific strategic decision and is distinct from overall environmental uncertainty (Elbanna and Child, 2007b). It refers to the clarity of the information to be collected, the uncertainty surrounding the actions to be taken in implementing the decision and the difficulty of predicting the outcomes of the decision (Papadakis et al., 1998). We expect that when managers cannot collect enough or proper information on the decision being implemented, or do not know what information to collect or even analyze, the quality of decision implementation may be particularly low. Hence:

Hypothesis 5: The uncertainty of decision implementation will be negatively related to the quality of decision implementation. 


\section{METHODOLOGY}

\section{Sampling issues}

The population of the study consists of Turkey’s Top 1,000 Industrial Enterprises and was obtained from the database of Istanbul's Chamber of Industry (ICI), but 113 firms for which no (postal) address was supplied were excluded from the population, resulting in a final population of 887 firms. Data were collected from the top managers of these 887 firms by mail survey and follow-ups conducted by a professional market research company, which had previously handled this type of research for various universities. Overall, 116 firms from 11 industries responded to the survey resulting in a participation rate of $13.08 \%$.

Of the 116 responding firms, 109 (94\%) were privately owned. 24 of the firms (20.7\%) had 249 or fewer employees, 23 (19.8\%) had 250-499 employees, and 69 (59.5\%) had more than 500 employees. We compared whether responding and non-responding firms differ in terms of number of employees and total assets. T-tests were insignificant showing that the results can be generalised to the population.

\section{Respondents}

The respondents consisted of 100 men (86.2\%) and 16 women (13.8\%). Of the 116 respondents, 63 (54.3\%) had a bachelor’s degree, 44 (37.9\%) had a master’s degree, six (5.2\%) had a PhD degree and three respondents had other degrees (2.6\%). 36\% of the respondents comprised presidents, CEOs or general managers, 15\% vice presidents, 22\% chief officers and 26\% directors. This participation at the highest level of the firms in our sample indicates that the responses come from key decision makers who are familiar with the questions in the survey instrument. Of the 116 respondents, only 5 (4.3\%) had 
occupied their current position for a year, 12 (10.3\%) had done so for two years, and the remaining 99 (85.4\%) for three or more years.

\section{Questionnaire development and measures}

All the questions in the questionnaire represent scales adapted from papers published in top management journals. To ensure that the translation of the scales into Turkish would not cause respondents any problems of understanding, we first translated the questions from English to Turkish. Next, the Turkish version of the questionnaire was translated into English by a bilingual researcher. We compared this English questionnaire to the original scales available in English. In addition, three experienced faculty members and two $\mathrm{PhD}$ students who are bilingual in English and Turkish reviewed the questionnaire. Finally, a pilot study with four managing directors from Turkish firms was conducted.

The unit of the analysis was set at the strategic decision level. Appendix 1 shows all the measures used in this study. On the lines of previous research, we controlled for the effects of four important variables - one environmental variable (i.e., munificence), one organizational variable (i.e., firm size) and two decision-related variables (i.e., familiarity and agreement with the decision). The response format for all questions was a five point Likert scale.

\section{Reliability and validity}

The psychometric properties of the constructs were evaluated by estimating the Cronbach's alpha reliability coefficient and the item-total correlation. The reliability estimates of all variables ranged between 0.76 and 0.87 for all scales. Moreover the itemtotal correlations for all items were well above 0.30 . The above results suggest an adequate degree of internal consistency. 
We used principal component analysis to assess construct validity. The total amount of variance explained by the six extracted factors is $70 \%$. With one exception, 0.37 , each factor is defined by variables with loadings higher than 0.45 (Hair et al., 1998). The results indicate loadings which are consistent with expectations. Rotated factors patterns show that the measurement instruments of this study meet the convergent and discriminant criteria of validity. Confirmatory Factor Analysis (CFA) analysis also confirmed that the measurement instruments have the convergent and discriminant validity, as we explain below.

We used the Harman's one-factor test in order to assess the existence of common method bias. Results showed several factors with the first one accounting for a low proportion of the variance (less than 30\%) suggesting that common method bias is not a problem in this study.

\section{RESULTS}

Table 1 presents the means, standard deviations (S.D.) and correlation coefficients for the entire sample $(\mathrm{N}=116)$. The table shows that trust $(\mathrm{r}=0.42, \mathrm{p}<0.001)$, participation $(\mathrm{r}$ $=0.38, \mathrm{p}<0.001)$ and past performance $(\mathrm{r}=0.39, \mathrm{p}<0.001)$ are positively correlated with the quality of decision implementation, whereas speed of implementation $(r=-0.17, p<$ $0.10)$ and implementation uncertainty $(r=-0.52, \mathrm{p}<0.001)$ are negatively correlated.

Insert Table 1 here 


\section{Analytic approach}

The data were analyzed using CFA and path analysis with the SPSS/AMOS 18 structural equation modeling package. ${ }^{2}$ Before analyzing the hypothesized model, the fit of a CFA model to the observed data was evaluated to further assess measurement scales and determine if the items loaded on their respective scales. Traditional goodness-of-fit measures were used to assess the fit of the model — incremental fit index (IFI), comparative fit index (CFI), and root mean square error of approximation (RMSEA). Values above 0.9 for IFI, and CFI indicate a good model fit; while a value below 0.08 for RMSEA indicates a good model fit (Bagozzi and Youjae, 1988).

\section{Assessment of measurement scales}

We purified our measures by assessing their reliability and validity before testing the hypothesized model. After conducting exploratory factor and reliability analyses to purify our measures, as discussed above, our measures were then subjected to CFA in order to assess their validity, using parceling because of sample size restrictions (Little et al., 2002). As shown in Table 2, the results of the CFA indicated a good model fit $(\chi 2=80.22$, degrees of freedom $[\mathrm{df}]=51, \mathrm{p}=0.01, \chi 2 / \mathrm{df}=1.57, \mathrm{IFI}=0.94, \mathrm{CFI}=0.94, \mathrm{RMSEA}=0.07$, confidence interval $[\mathrm{CI}]=0.039-0.099$, PClose $=0.13)$. The loadings estimates ranged from 0.78 to 0.86 for quality of decision implementation, 0.66 to 0.98 for trust, 0.47 to 0.87 for participation, 0.66 to 0.90 for implementation uncertainty, 0.67 to 0.86 for environmental munificence, and 0.46 to 0.93 for familiarity with the decision.

\section{Insert Table 2 here}

\footnotetext{
${ }^{2}$ We thank the Managing Editor and one of the two anonymous reviewers for bringing our attention to the use of Structural Equation Modeling application.
} 


\section{Hypothesis testing}

Path analysis was used to test the hypotheses and evaluate the model's goodness of fit with the data. Path analysis is another name for structural equation modeling (SEM) technique (Kline, 2011). While path analysis evaluates a model that employs only the observed (manifest or indicator) variables, SEM analysis evaluates a model that includes both observed and unobserved (latent) variables (Garson, 2014). Both techniques can be used to simultaneously test the model fit and the relationships among variables of interest (Geffen, Straub, and Boudreau, 2000). We opted for path analysis in our study because SEM requires a larger sample size and using it with a small or moderate sample size (such as 116 in our study) could generate invalid estimations (Nasser and Wisenbaker, 2003). A ratio of at least five observations per parameter estimate is suggested as the minimum sample size requirement for path analysis to produce reliable estimates (Hair et. al., 1998). AMOS output (not reported here) calculates the number of parameters estimated for our final model as 19. This means that the sample size of this study should be at least 90 . Therefore, our sample size of 116 satisfies the minimum sample size requirement. To estimate the model fit and path coefficients, maximum likelihood (ML) estimation method was used, which is the default estimation method in AMOS. The initial model produced poor fit indices (e.g., $\chi 2=114.71, \mathrm{df}=36, \mathrm{IFI}=0.48$, CFI $=0.45$, RMSEA $=0.14$, PClose $=0.000$ ), suggesting that the model does not fit the data well. To improve the model fit, modification indices (MIs) were used. Provided by AMOS, MIs indicate the expected increase in the model fit if the constrain that the two (independent) variables cannot be correlated is removed (Byrne, 2010). Examination of the MIs suggested that the initial model can be improved by allowing correlations among a number of pair of independent 
variables. These correlations, suggested by MIs, do not imply new hypotheses and should be added to the model based on related literature, informal theories, and common sense (Mertler and Vannatta, 2005). Following Garson (2014), the suggested additions were carried out one-by-one, beginning with the pair of correlation between trust and agreement as it was the pair with the largest MI (15.99). After each addition, the model was reestimated, and this process was repeated (with the related literature and informal theories in mind) for the remaining pairs until a good fitting model was achieved. The resulting (improved) model (not shown here, but available upon request) explained $43 \%$ of the variation in the dependent variable (i.e., implementation quality) and had a good fit (e.g., $\chi^{2}$ $=31.22, \mathrm{df}=26, \mathrm{IFI}=0.97, \mathrm{CFI}=0.96, \mathrm{RMSEA}=0.04$, PClose $=0.57)$. However, of the four control variables, three control variables; namely, munificence $(p=0.90)$, size $(p=$ 0.73), and familiarity ( $\mathrm{p}=0.91$ ) were not significant. To not unnecessarily increase the number of parameters to be estimated by using insignificant variables; and thus, achieve a more parsimonious model, this model was trimmed by dropping the three insignificant control variables (Garson, 2014).

The new and more parsimonious (final) model, which included one control variable, explained the same amount of variation (43\%) in the dependent variable as the full model (i.e., as the above improved model), which included four control variables. Furthermore, with one slight exception (the estimate of implementation uncertainty being $(-0.41)$ in the full model, but $(-0.40)$ in the trimmed model), the magnitude and directions of the estimated coefficients were the same in both models, further supporting that the trimmed model was more parsimonious (Garson, 2014). The results of the trimmed model are reported in Table 2 and Figure 2. 
Table 2 shows that the final model fits the data well $(\chi 2=13.93$, degrees of freedom $[\mathrm{df}]=9, \chi 2 / \mathrm{df}=1.55, \mathrm{IFI}=0.96, \mathrm{CFI}=0.96, \mathrm{RMSEA}=0.07$, confidence interval $[\mathrm{CI}]=$ 0.000-0.136, PClose $=0.29$ ). As Figure 2 shows, the whole model explains $43 \%$ of the variation in the dependent variable. The paths from trust $(\beta=0.26, \mathrm{t}=3.14, \mathrm{p}<0.01)$, participation $(\beta=0.17, \mathrm{t}=2.16, \mathrm{p}<0.05)$, past performance $(\beta=0.26, \mathrm{t}=3.43, \mathrm{p}<0.001)$, to the quality of decision implementation were all positively significant. These results confirm Hypotheses 1, 2 and 3, suggesting that trust during the strategic decision making, level of participation in the strategic decision making, and past performance are positively related to the quality of decision implementation.

The paths from speed of decision implementation $(\beta=-0.16, \mathrm{t}=-2.32, \mathrm{p}<0.05)$ and uncertainty of decision implementation $(\beta=-0.40, t=-5.20, p<0.001)$ to the quality of decision implementation were negatively significant. Hence, Hypothesis 4, that the speed of decision implementation is positively related to the quality of decision implementation, is not supported; while Hypothesis 5, that the uncertainty of decision implementation is negatively related to the quality of decision implementation, is confirmed.

Insert Figure 2 here

\section{DISCUSSION}

This paper examined the antecedents of the quality of decision implementation. The results reported here support the view that the quality of decision implementation is shaped simultaneously by multiple factors related to team processes (i.e., trust and participation), firm characteristics (i.e., performance) and implementation characteristics (i.e., speed and 
uncertainty of decision implementation). The findings of this study have implications for both theory and practice.

From the standpoint of theory, they suggest that the outcomes of decision implementation cannot be modeled in terms of a single perspective and that multiple determinants from different layers of context affect the quality of decision implementation. Our empirical evidence demonstrates that it is not the team processes, or the firm characteristics or the implementation characteristics which shape the quality of implementation quality but rather their simultaneous effects. The latter suggests that a combination of different perspectives is needed in order to shed light on the determinants of implementation outcomes. Still, prior implementation studies have mainly adopted fragmented perspectives in their models. Looking forward, the findings reported here demonstrate the usefulness of using integrative frameworks in explaining implementation outcomes and calls for future studies using variables from other layers of context not examined here (e.g., managerial characteristics) or from other important strategy implementation studies emphasizing organization structure (Chandler, 1962), culture (Brenes, Mena, and Molina, 2008) or power issues (Pfeffer, 1981).

From the standpoint of practice, our study highlights some important determinants of the quality of decision implementation. These determinants include trust, participation, past performance, implementation speed, and implementation uncertainty. These findings collectively suggest that managers should be attentive to a number of issues when implementing strategic decisions. If not taken into account, these issues could negatively affect implementation quality. 
Specifically, consistent with our first hypothesis, trust among team decision makers positively influences the quality of decision implementation which might be attributed to the fact that trust acts as a mechanism for conflict resolution and for reducing organizational politics. This finding suggests that organizations should build trust among decision makers from different layers in the hierarchy. One particular way of achieving this could be through establishing and nurturing open communication channels where senior level managers timely communicate various aspects of the implementation process to all of their subordinates (to the lower-level managers). Frequent use of this kind of vertical communication channels could generate shared understanding or consensus (Rapert, Velliquette, and Garretson, 2002), which can enhance the feeling of togetherness, increase trust, and reduce the perception of conflict and politics among team members. The importance of communication for the formation of trust in Turkish context was established by Asunakutlu (2006), among others, who showed that the quality of communication of employees with their managers is significantly related to their trust in the management. Another mechanism for trust formation among decision makers could be through enhancing perceived level of justice among decision makers. This can be achieved by instilling consistency, fairness, honesty, and politeness into the procedures and (managerial) interactions that exist in the organization, as argued by Dayan, Di Benedetto, and Colak (2009), in their study of 127 Turkish firms. The importance of justice, especially interactional justice, for the formation of trust in Turkish context was also highlighted by Ertürk (2007).

Moreover, we found that participation is positively related to the quality of decision implementation. As we theorized, participation leads to good implementation outcomes 
through triggering consensus over and commitment to the strategic decision. This finding suggests that organizations should create and ensure a climate of participation among various managers from different levels for higher quality implementation. A climate of participation can be achieved by involving managers early in the decision making process (i.e., by collecting and integrating their suggestions into the decisions being made and through meetings where managers can exchange their ideas and expectations about various aspects of the implementation process). Early involvement and managerial meetings allow decision makers to internalize implementation process; and thus, promote a sense of ownership, and higher level of commitment to the implementation process, which eventually will increase the implementation quality. Our suggestion that organizations should create a climate of participation coincides with the findings of Bakan and Buyukbese (2008), who indicated that more than $90 \%$ of respondents, in their sampled Turkish firms, viewed participation as an important factor for the quality of decisionmaking and implementation.

Our findings also suggest that well performing firms seem to be in a position to implement decisions better than poorly performing ones. This finding is consistent with our expectations and suggests that organizations should, and can, firmly base their implementation activities on their strong financial infrastructure to design better budgets, metrics, and reward structures, which are all reported as key success factors of successful implementation (Allio, 2005). For example, Koseoglu, Barca, and Karayormuk (2009), in their study of 483 Turkish managers, identified compensation practices as an important factor that influences the success of strategy implementation. Therefore, our finding that well performing firms implement their decisions better than poorly performing ones 
suggest that organizations should support their implementation activities by better budgets, metrics, and reward (compensation) structures. Lack of financial strength to generate this ability can result in poor implementation quality.

Another variable which was found to influence the quality of implementation was the speed with which it took place. We hypothesized that speed would be positively related to the quality of decision implementation. Contrary to our expectation, however, we found that implementation speed is negatively related to implementation quality. This finding probably means that decisions which are very quickly implemented result in bad outcomes (i.e., "speed costs money") by leading the firm to a "speed trap” (Perlow, Okhuysen, and Repenning, 2002) because implementers, in such situations, may ignore important details and act without due care. Maule, Hockey, and Bdzola (2000), for example, found in their experimental study that individuals under time pressure spend less time on negative information, which could contain important details affecting the decision.

This is consistent with the studies on individual decision making in psychology. Such a line of research suggests that time pressure (i.e., speed) may "close off" the minds of implementers (e.g., top managers, middle level managers, front line employees) (De Dreu and Weingart, 2003), discouraging them from "a thorough and in-depth processing of information” (Kocher and Sutter, 2006: p.378), which might be necessary before the formulated decisions could be successfully implemented; omitting it might impair their information processing capacities, and consequently, encourage them to depend more on rules of thumb or heuristics in their judgments.

However, making or implementing decisions with heuristics will introduce cognitive bias to the process, which generates systematic errors (Das and Teng, 1999). These 
systematic errors resulting from implementers' cognitive bias could reduce the quality of decision implementation. The experimental study of Kocher and Sutter (2006) provides empirical support for this line of thinking. In particular, these writers found that time pressure reduces the quality of decision making. Our finding indicates that the same holds for decision implementation.

Finally, we found that the uncertainty of decision implementation is negatively related to the quality of decision implementation, since in such decisions, team members cannot gather the proper amount of information or they feel uncertain which actions to take. This finding suggests that organizations should be attentive to the uncertainties surrounding the decision being implemented. Every implementation entails a certain amount of change that may produce discomfort, speculation, and confusion, which in turn produce uncertainty and negatively impacts implementation quality. To effectively address this problem, managers should establish proper mechanisms to minimize the implementation uncertainty and clarify confusions and misunderstandings about the actions that need to be carried out to implement the decision in question. One particular way of achieving this could be through developing implementation or action plans that clearly spell out the objectives, activities, responsibilities, and timeline involved in the implementation process. Organizations should also have an evaluation mechanism where regular follow-ups of these action plans are conducted because implementation is a process and uncertainty could arise in any point of this process.

In a nutshell, although the previous findings should be interpreted with the limitations of this study in mind, it still can offer fruitful avenues for future research. The limitations are that the data were collected from a single country (i.e. Turkey), from a single 
respondent and at a single point in time which is consistent with several prior studies (e.g., Ashill and Jobber, 2013). Moreover, although we carefully reviewed relevant research in selecting our explanatory variables, we cannot claim that they are exhaustive. The constructs considered in this study are an important subset of a large number of constructs that could potentially influence strategy implementation. Hence, a more accurate understanding of the determinants of the quality of decision implementation, requires the examination of models including additional sets of explanatory variables from past strategy implementation studies on organizational structure (Chandler, 1962; Olson, Slater, and Hult, 2005), variables related to the McKinsey 7S Framework (e.g., leadership style, systems, skills, strategy etc.), culture (Brenes et al., 2008), power issues and the political context of the organization (Pfeffer, 1981), balanced scorecard as a tool in implementing strategies (Kaplan and Norton, 1996) and evidence based management, which suggests the use of best-practices (benchmarking) in strategy implementation (Pfeffer and Sutton, 2006).

Looking forward, future research should investigate relationships which are more complex by incorporating moderating and/or mediating effects into our model. For example, investigating the moderating impact of technological and market uncertainty on the examined relationships may be an avenue for future research. Moreover, we welcome studies investigating the linkage between the quality of decision implementation, decision success and firm performance (Meissner and Wulf, 2014). Doing so will help executives to understand the contributions which decision implementation make to the success or failure of their decisions.

To conclude, our results showed that integrative frameworks like the ones reported here can provide useful knowledge on the determinants of the quality of decision 
implementation. We hope that our paper will encourage more research in this important area to better understand decision implementation. 


\section{Figure 1:}

\section{Determinants of the Quality of Strategic Decision Implementation}

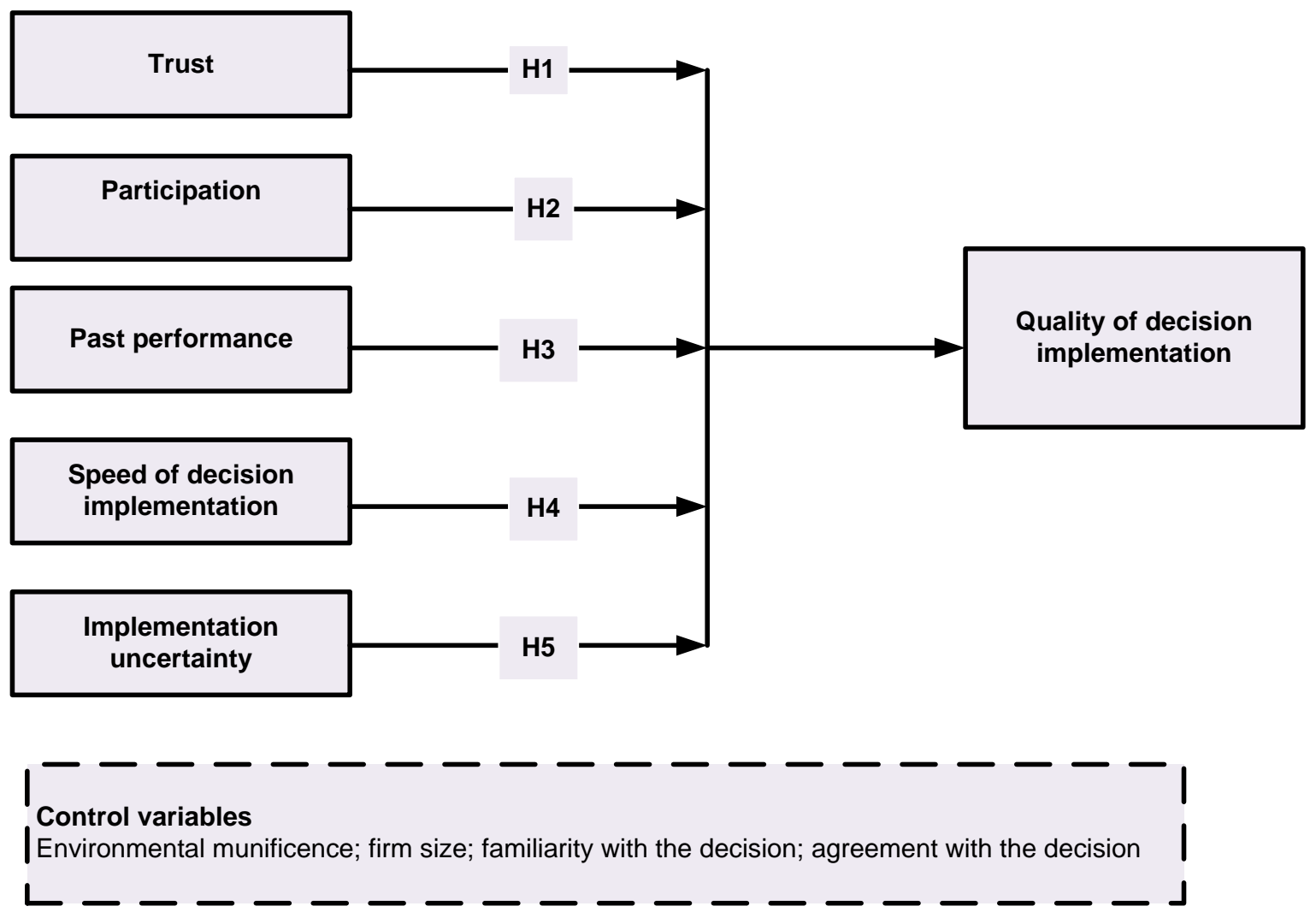


Figure 2:

Final Path Model with Standardized Path Coefficients, T Values, and Significance Levels

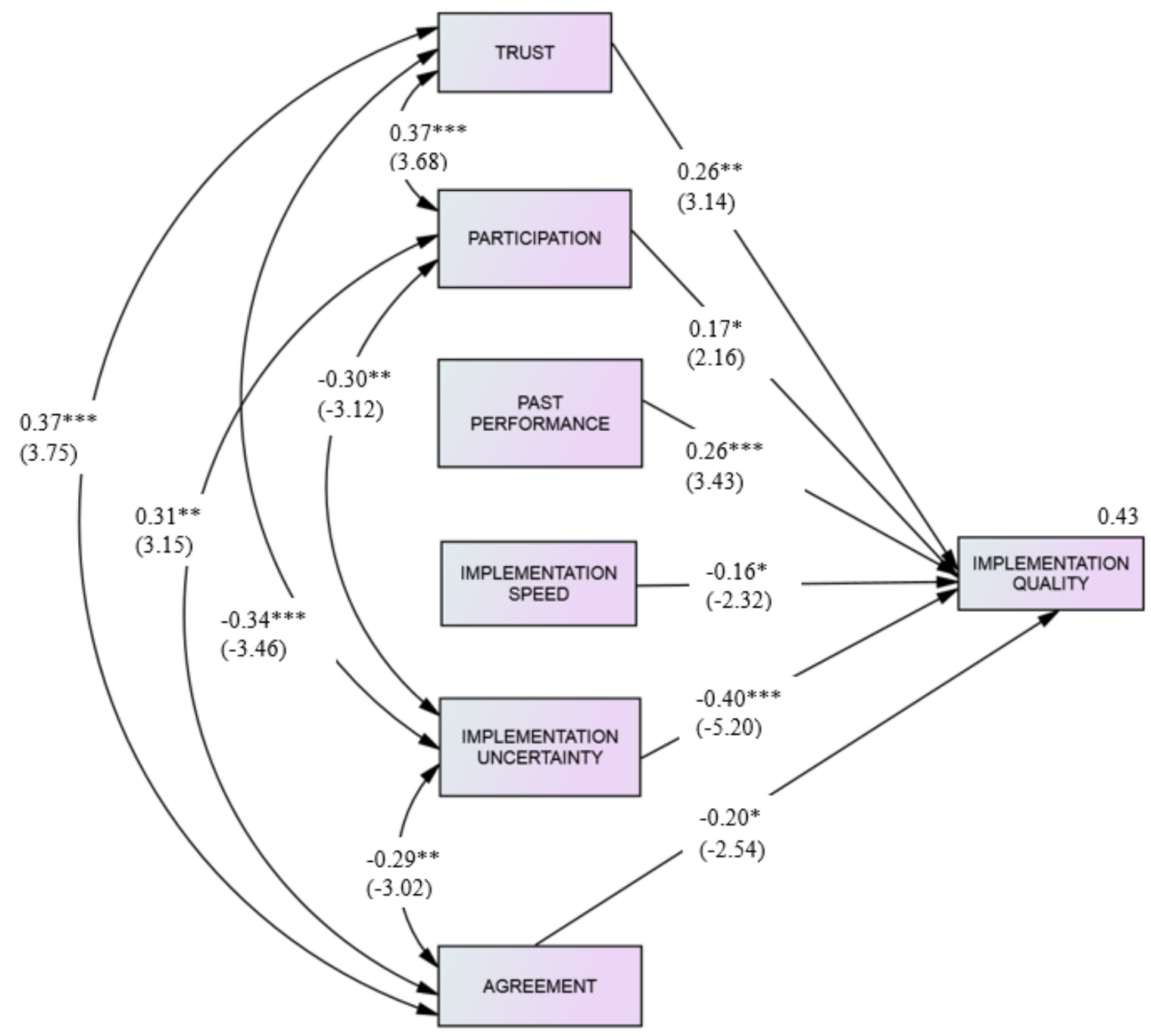

Notes: T values are given in parentheses; $\mathrm{N}=116 ;{ }^{*} \mathrm{p}<0.05,{ }^{* *} \mathrm{p}<0.01, \mathrm{p} * * *<0.001$ 
Table 1

Descriptive Statistics and Correlations among Variables

\begin{tabular}{|c|c|c|c|c|c|c|c|c|c|c|c|c|}
\hline Variables & Mean & S.D. & Alpha & 1 & 2 & 3 & 4 & 5 & 6 & 7 & 8 & 9 \\
\hline $\begin{array}{l}\text { 1. Quality of decision } \\
\text { implementation }\end{array}$ & 3.80 & 0.68 & 0.87 & 1 & & & & & & & & \\
\hline 2. Trust & 4.47 & 0.61 & 0.81 & $0.42^{* * * *}$ & 1 & & & & & & & \\
\hline 3. Participation & 3.98 & 0.82 & 0.76 & $0.38^{* * *}$ & $0.37^{* * *}$ & 1 & & & & & & \\
\hline 4. Past performance & 0.35 & 0.53 & NA & $0.39^{* * * *}$ & $0.24^{* *}$ & $0.25^{* *}$ & 1 & & & & & \\
\hline $\begin{array}{l}\text { 5. Speed of decision } \\
\text { implementation }\end{array}$ & 12.02 & 9.62 & NA & $-0.17^{+}$ & 0.07 & -0.05 & -0.07 & 1 & & & & \\
\hline $\begin{array}{l}\text { 6. Implementation } \\
\text { uncertainty }\end{array}$ & 1.89 & 0.75 & 0.81 & $-0.52^{* * * *}$ & $-0.34^{* * * *}$ & $-0.31^{* *}$ & $-0.18^{+}$ & 0.02 & 1 & & & \\
\hline $\begin{array}{l}\text { 7. Environmental } \\
\text { munificence }\end{array}$ & 3.25 & 0.99 & 0.76 & 0.04 & 0.07 & 0.02 & $0.18^{+}$ & $0.30^{* * *}$ & -0.09 & 1 & & \\
\hline 8. Firm size & 2.73 & 0.45 & NA & 0.02 & -0.02 & 0.02 & -0.03 & -0.02 & $-0.16^{+}$ & 0.15 & 1 & \\
\hline $\begin{array}{l}\text { 9. Familiarity with the } \\
\text { decision }\end{array}$ & 3.81 & 0.87 & NA & 0.13 & $0.20^{*}$ & 0.13 & $0.19^{*}$ & 0.01 & -0.05 & $0.16^{+}$ & $0.18^{+}$ & 1 \\
\hline $\begin{array}{l}\text { 10. Agreement with the } \\
\text { decision }\end{array}$ & 4.62 & 0.72 & NA & 0.12 & $0.37^{* * *}$ & $0.31^{* *}$ & $0.18^{+}$ & -0.04 & $-0.29^{* *}$ & -0.01 & 0.03 & -0.05 \\
\hline
\end{tabular}

Notes: $\mathrm{N}=116,{ }^{+} \mathrm{p}<0.10,{ }^{*} \mathrm{p}<0.05,{ }^{* *} \mathrm{p}<0.01,{ }^{* * *} \mathrm{p}<0.001$; NA: Non Applicable 
Table 2

Goodness-of-Fit Indices

\begin{tabular}{|l|c|c|c|c|c|c|c|}
\hline Model & $\chi 2$ & df & $\chi 2 /$ df & IFI & CFI & RMSEA & PClose \\
\hline CFA model & 80.22 & 51 & 1.57 & 0.94 & 0.94 & 0.07 & 0.13 \\
\hline Final path model & 13.93 & 9 & 1.55 & 0.96 & 0.96 & 0.07 & 0.29 \\
\hline
\end{tabular}


Appendix 1

Measurement Items

Quality of decision implementation (sources: Elbanna and Child, 2007a; Miller, 1997)

(1) Everything intended to be done in the implementation of this decision was done within the expected time period.

(2) Everything done during the implementation of this decision performs as expected.

(3) The method of implementation of this decision was satisfactory to those involved in, or affected by, the implementation.

(4) The precise details of the implementation activities were well-decided.

(5) If we had the chance to implement this decision again, many changes should be made (reversed).

(6) In general, this decision was well-implemented.

Trust (sources: Ford and Goia, 2000; Schaffer and Willaeur, 2003)

(1) How would you characterize the level of trust among the people involved in this decision?

(2) How confident were the participants in this decision that they could rely on each other?

(3) Participants in this decision openly shared important information.

Participation (sources: Papadakis et al., 1998; Elbanna, 2008)

To what extent did the following individuals participate in making the selected decision?

(1) CEO/managing director; (2) senior managers; (3) middle managers; (4) members of the supervisory management/lower managers

Performance (source: Wiersema and Zhang, 2011)

Return on assets adjusted for industry effects

Speed of decision implementation (sources: Dooley et al. 2000; Forbes, 2005)

The number of months from the start of the implementation process to its completion

Uncertainty of decision implementation (sources: Beach and Mitchell, 1978; Papadakis et al. 1998)

(1) It was not at all clear what kind of information we should have collected to implement this decision.

(2) We were very uncertain about the actions that should have been taken in order to implement this decision.

(3) It was difficult to predict the outcomes of the various courses of action we considered in implementing this decision.

(4) There was general uncertainty surrounding the implementation of this decision.

Environmental munificence (sources: Elbanna et al., 2013; Khandwalla, 1977)

(1) Our environment is safe and there is little threat to the survival and well-being of the company.

(2) There is richness in opportunities of investment, marketing and profitability.

(3) There is high demand in our environment, and our products enjoy customer acceptance.

Firm size (source: Petrou and Thanos, 2014)

The log number of full-time employees

Familiarity with the decision (source: Papadakis et al. 1998)

(1) How often do decisions of the same nature as the case under investigation arise in your company?

(2) To what extent did decision-makers feel familiar with making decisions of this nature?

Agreement with the decision (source: Elbanna and Child, 2007a)

To what extent did you agree with this decision? 


\section{References}

Allio, M. K. (2005), ‘A short, practical guide to implementing strategy', Journal of Business Strategy, Vol. 26, No. 4, pp. 12-21.

Amason, A. C. and Mooney, A. C. (2008), 'The Icarus paradox revisited: How strong performance sows the seeds of dysfunction in future strategic decisionmaking', Strategic Organization, Vol. 6, No. 4, pp. 407-434.

Andersen, T. J. (2004), 'Integrating decentralized strategy making and strategic planning processes in dynamic environments', Journal of Management Studies, Vol. 41, No. 8, pp. 1271-1299.

Andersen, T. J. and Nielsen, B. B. (2009), 'Adaptive strategy making: The effects of emergent and intended strategy modes', European Management Review, Vol. 6, No. 2, pp. 94-106.

Asunakutlu, T. (2006). 'Çalışanlar ile yöneticiler arasında güven duygusunun araştırılması: Turizm sektöründe bir uygulama' ['Analysis of feeling of trust between employees and managers: An application in tourism sector'], Dokuz Eylül Üniversitesi Sosyal Bilimler Enstitüsü Dergisi, Vol. 8, No: 4, pp.16-33.

Ashill, N. and Jobber, D. (2013), 'The effects of experience on managerial decisionmaking uncertainty', Journal of General Management, Vol. 39, No. 1, pp. 81110.

Ashmos, D. P., Duchon, D. and McDaniel, R. R. (1998), 'Participation in strategic decision making: The role of organizational predisposition and issue interpretation', Decision Sciences, Vol. 29, No. 1, pp. 25-51.

Atuahene-Gima, K. and Murray, J. Y. (2004), 'Antecedents and outcomes of marketing strategy comprehensiveness', Journal of Marketing Research, Vol. 68, pp. 33-46.

Bagozzi, R. P. and Youjae, Y. (1988), 'On the evaluation of structural equation models', Journal of the Academy of Marketing and Science, Vol. 16, No. 1, pp. 74-94.

Bakan, İ. and Buyukbese, T. (2008). 'Katılımc1 karar verme: Kararlara katılım konusunda çalışanların düşüncelerine yönelik bir alan çalışması' ['Participative decision making'], Süleyman Demirel Üniversitesi İktisadi ve İdari Bilimler Fakültesi Dergisi, Vol. 13, No: 1, pp. 29-56.

Baum, J. R. and Wally, S. (2003), 'Strategic decision speed and firm performance', Strategic Management Journal, Vol. 24, pp. 1107-1129.

Beach, L. R. and Mitchell, T. R. (1978), 'A contingency model for the selection of decision strategies', Academy of Management Review, Vol. 3, pp. 439-449.

Brenes, E. R., Mena, M. and Molina, G. E. (2008), 'Key success factors for strategy implementation in Latin America', Journal of Business Research, 61: 590598.

Bourgeois, L. J. and Eisenhardt, K. M. (1988), 'Strategic decision processes in high velocity environments: Four cases in the microcomputer industry', Management Science, Vol. 34, No. 7, pp. 816-835.

Byrne, B.M. (2010). 'Structural equation modeling with AMOS: Basic concepts, applications, and programming' ( $2^{\text {nd }}$ ed), New York, NY: Taylor and Francis.

Chandler, A. D. (1962). Strategy and structure. New York: Doubleday.

Clark, K. and Collins, C. J. (2002). 'Strategic decision-making in high velocity environments: A theory revisited and a test', Vol. Electronic version. Retrieved 10/04/2013 from Cornell University, ILR School site: http://digitalcommons.ilr.cornell.edu/articles/566. 
Das, T. K. and Teng, B. S. (1999), 'Cognitive biases and strategic decision processes: An integrative perspective', Journal of Management Studies, Vol. 36, No. 6, pp. 757-778.

Dayan, M., Di Benedetto, C. A. and Colak, M. (2009), 'Managerial trust in new product development projects: Its antecedents and consequences', $R$ and $D$ Management, Vol. 39, No. 1, pp. 21-37.

De Dreu, C. and Weingart, L. (2003), 'Task versus relationship conflict, team performance and team member satisfaction: A meta-analysis', Journal of Applied Psychology, Vol. 88, No. 4, pp. 741-749.

Delerue, H. (2005), 'Conflict resolution mechanisms, trust and perception of conflict in contractual agreements', Journal of General Management, Vol. 30, No. 4, pp. 11-26.

Demirbag, M., Tatoglu, E., Glaister, K. W. and Zaim, S. (2010), 'Measuring strategic decision making efficiency in different country contexts: A comparison of U.K. and Turkish firms', Omega, Vol. 38, No. 1/2, pp. 95-104.

Dooley, R. S., Fryxell, G. E. and Judge, W. Q. (2000), 'Belaboring the not-soobvious: Consensus, commitment, and strategy implementation speed and success', Journal of Management, Vol. 26, No. 6, pp. 1237-1257.

Eisenhardt, K. M. (1989), 'Making fast strategic decision in high velocity environments', Academy of Management Journal, Vol. 32, No. 3, pp. 543-576.

Elbanna, S. (2006), 'Strategic decision making: Process perspectives', International Journal of Management Reviews, Vol. 8, No. 1, pp. 1-20.

Elbanna, S. (2008), 'Planning and participation as determinants of strategic planning effectiveness: Evidence from the Arabic context', Management Decision, Vol. 46, No. 5, pp. 779-796.

Elbanna, S. and Child, J. (2007a), 'Influences on strategic decision effectiveness: Development and test of an integrative model', Strategic Management Journal, Vol. 28, pp. 431-453.

Elbanna, S. and Child, J. (2007b), 'The influence of decision, environmental and firm characteristics on the rationality of strategic decision-making', Journal of Management Studies, Vol. 44, No. 4, pp. 561-591.

Elbanna, S., Child, J. and Dayan, M. (2013), 'A model of antecedents and consequences of intuition in strategic decision-making: Evidence from Egypt', Long Range Planning, Vol. 46, No. 1-2, pp. 149-176.

Eker, M. (2008). 'The effect of the relationship between budget participation and jobrelevant information on managerial performance', Ege Akademik Bakış, Vol. 10, No. 1, pp. 183-198.

Ertürk, A. (2007). 'Increasing organizational citizenship behaviours of Turkish academicians: Mediating role of trust in superiors on the relationship between organizational justice and citizenship behaviours', Journal of Managerial Psychology, Vol. 22, No. 3, pp. 257-270.

Forbes, D. P. (2005), 'Managerial determinants of decision speed in new ventures', Strategic Management Journal, Vol. 26, pp. 355-366.

Ford, C. M. and Gioia, D. A. (2000), 'Factors influencing creativity in the domain of managerial decision making', Journal of Management, Vol. 26, No. 4, pp. 705-732.

Garson, G.D. (2014). Path analysis, Asheboro, NC: Statistical Associates Publishers.

Gefen, D., Straub, D.W. and Boudreau, M-C. (2000), 'Structural equation modeling and regression: Guidelines for research practice', Communications of the Association for Information Systems, Vol. 4, No. 7, pp. 1-70. 
Gilbert, D., Halliday, S., Heavey, C. and Murphy, E. (2011), 'Enhancing performance: Bringing trust commitment and motivation together in organisations', Journal of General Management, Vol. 36, No. 3, pp. 1-18.

Hair, J. F., Anderson, R., Tatham, R. and Black, W. C. (1998). Multivariate data analysis with readings ( $5^{\text {th }}$ eds.), London: Prentice-Hall.

Jiang, X., Gao, S. and Li, Y. (2008), 'How trust, dependence and prior ties influence the stability of alliances', Journal of General Management, Vol. 34, No. 1, pp. $1-17$.

Judge, W. Q. and Miller, A. (1991), 'Antecedents and outcomes of decision speed in differential environmental context', Academy of Management Journal, Vol. 34, No. 2, pp. 449-463.

Kaplan, R. S. and Norton, D. P. (1996). 'The balanced scorecard: Translating strategy into action. Boston, MA: Harvard Business School Press.

Kellermanns, F. W., Walter, J., Floyd, S. W., Lechner, C. and Shaw, J. C. (2011), 'To agree or not to agree? A meta-analytical review of strategic consensus and organizational performance', Journal of Business Research, Vol. 64, No. 2, pp. 126-133.

Kline, R. B. (2011). Principles and practice of structural equation modeling ( $3^{\text {rd }}$ eds), New York: Guilford Press.

Khandwalla, P. N. (1977). The design of organizations. New York: Harcourt Brace Jovanovich.

Kocher, M. G. and Sutter, M. (2006), 'Time is money-time pressure, incentives, and the quality of decision-making', Journal of Economic Behavior and Organization, Vol. 61, No. 3, pp. 375-392.

Koseoglu, M. A., Barca, M. and Karayormuk, K. (2009). 'A study on the causes of strategies failing to success', Journal of Global Strategic Management, Vol. 6, pp. 77-91.

Krishnan, R., Martin, X. and Noorderhaven, N. G. (2006), 'When does trust matter to alliance performance?', Academy of Management Journal, Vol. 49, pp. 894917.

Little, T. D., Cunningham, W. A., Shahar, G. and Widaman, K. F. (2002), 'To parcel or not to parcel: Exploring the question, weighing the merits', Structural Equation Modeling, Vol. 9, No. 2, pp. 151-173.

Makadok, R. C. (1998), 'Can first-mover and early-mover advantages be sustained in an industry with low barriers to to entry/imitation?', Strategic Management Journal, Vol. 19, No. 7, pp. 683-696.

Maule, A. J., Hockey, G. R. J. and Bdzola, L. (2000), 'Effects of time-pressure on decision-making under uncertainty: Changes in affective state and information processing strategy', Acta Psychologica, Vol. 104, No. 3, pp. 283-301.

Meissner, P. and Wulf, T. (2014), 'Antecedents and effects of decision comprehensiveness: The role of decision quality and perceived uncertainty', European Management Journal, Vol. 32, No. 4, pp. 625-635.

Mertler, C. and Vannatta, R. (2005). Advanced and multivariate statistical methods: Practical application and interpretation ( $3^{\text {rd }}$ eds). Gendale, CA: Pyrczak Publishing.

Miller, C. C. (2008), 'Decisional comprehensiveness and firm performance: Towards a more complete understanding', Journal of Behavioral Decision Making, Vol. 21, No. 5, pp. 598-620.

Miller, S. (1997), 'Implementing strategic decisions: Four key success factors', Organization Studies, Vol. 18, No. 4, pp. 577-602. 
Nasser, F. and Wisenbaker (2003). 'A Monte Carlo study investigating the impact of item parceling on measures of fit in confirmatory factor analysis' Educational and Psychological Measurement, Vol. 63, No.5, pp. 729-757.

Noble, C. (1999), 'The eclectic roots of strategy implementation research', Journal of Business Research, Vol. 45, No. 2, pp. 119-134.

Nutt, P. C. (1999), 'Surprising but true: Half the decisions in organisations fail', Academy of Management Executive, Vol. 13, No. 4, pp. 75-90.

Olson, B. J., Parayitam, S. and Bao, Y. (2007), 'Strategic decision making: The effects of cognitive diversity, conflict, and trust on decision outcomes', Journal of Management, Vol. 33, No. 2, pp. 196-222.

Olson, E. M., Slater, S. F. and Hult, G. T. (2005). 'The importance of structure and process to strategy implementation', Business Horizons, Vol. 48, No. 1, pp. 47-54.

Papadakis, V. M. (1998), 'Strategic investment decision processes and organizational performance: An empirical examination’, British Journal of Management, Vol. 9, No. 2, pp. 115-132.

Papadakis, V. M., Lioukas, S. and Chambers, D. (1998), 'Strategic decision-making processes: The role of management and context', Strategic Management Journal, Vol. 19, pp. 115-147.

Papadakis, V. M., Thanos, I. C. and Barwise, P. (2010). 'Research on strategic decisions: Taking stock and looking ahead', in P. Nutt, and D. Wilson (Eds.), Handbook of Decision Making, pp. 31-69, Chichester: Wiley.

Parayitam, S. and Dooley, R. S. (2009), 'The interplay between cognitive- and affective conflict and cognition- and affect-based trust in influencing decision outcomes', Journal of Business Research, Vol. 62, No. 8, pp. 789-796.

Perlow, L. A., Okhuysen, G. A. and Repenning, N. P. (2002), 'The speed trap: Exploring the relationship between decision making and temporal context', Academy of Management Journal, Vol. 45, No. 5, pp. 931-955.

Peters, L. and Karren, R. (2009), 'An examination of the roles of trust and functional diversity on virtual team performance ratings', Group and Organization Management, Vol. 34, No. 4, pp. 479-504.

Petrou, A. P. and Thanos, I. C. (2014), "The "grabbing hand" or the "helping hand" view of corruption: Evidence from bank foreign market entries', Journal of World Business, Vol. 49, No. 3, pp. 444-454.

Pettigrew, A. (2003). 'Strategy as process, power and change', in S. Cummings, and D. Wilson (Eds.), Images of strategy, pp. 301-330, Oxford: Blackwell.

Pfeffer, J. (1981). Power in Organizations. Marshfield, MA: Pitman Publishing.

Pfeffer, J. and Sutton, R.I. (2006). 'Evidence based management, Harvard Business Review', Vol. 84, No. 1, pp. 62-74.

Porter, M. E. and Millar, V. E. (1985), 'How information gives you competitive advantage', Harvard Business Review, Vol. 63, No. 4, pp. 149-160.

Rajagopalan, N., Rasheed, A. M. A. and Datta, D. K. (1993), 'Strategic decision processes: Critical review and future directions', Journal of Management, Vol. 19, No. 2, pp. 349-385.

Rapert, M. I., Velliquette, A. and Garretson, J. A. (2002), 'The strategic implementation process evoking strategic consensus through communication', Journal of Business Research, Vol. 55, No. 4, pp. 301-310.

Riehl, J. W. (1988), 'Planning for total quality: The information technology component', Advanced Management Journal, Vol. 53, No. 4, pp. 13-19. 
Rodrigues, S. B. and Hickson, D. J. (1995), 'Success in decision making: Different organizations, differing reasons for success', Journal of Management Studies, Vol. 32, No. 5, pp. 655-678.

Schaffer, U. and Willauer, B. (2003), 'Strategic planning as a learning process', Schmalenbach Business Review, Vol. 55, pp. 86-107.

Simon, H. A. (1993), 'Strategy and organizational evolution', Strategic Management Journal, Vol. 14, No. S2, pp. 131-142.

Tatoglu, E. and Demirbag, M. (2008), 'Transition in the age of anxiety: The Turkish case', Journal of Management Development, Vol. 27, No. 7, pp. 653-659.

Wiersema, M. F. and Zhang, Y. (2011), 'CEO dismissal: the role of investment analysts’, Strategic Management Journal, Vol. 32, No. 11, pp. 1161-1182.

Wooldridge, B. and Floyd, S. W. (1990), 'The strategy process, middle management involvement, and organizational performance', Strategic Management Journal, Vol. 11, No. 3, pp. 231-241.

Zaheer, A. McEvily, B. and Perrone, V. (1998), 'Does trust matter? Exploring the effects of interorganizational and interpersonal trust on performance', Organization Science, Vol. 9, No. 2, pp. 141-159.

Zehir, C. and Ozsahin, M. (2006). 'Stratejik karar verme hızını etkileyen örgütsel, çevresel faktörler ve firma performansı ilişkisi: İmalat sektöründe bir saha çalışması' ['The organizational and environmental determinants of strategic decision speed and firm performance relation: A case study in manufacturing industry’], Gazi Üniversitesi İktisadi ve İdari Bilimler Fakültesi Dergisi, Vol.9, No.1, pp. 137-157 .

Zehir, C. and Özsahin, M. (2008). 'A field research on the relationship between strategic decision-making speed and innovation performance in the case of Turkish large-scale firms', Management Decision, Vol. 46, No. 5 pp. 709 724. 